\title{
Astrophyllite-alkali amphibole rhyolite, an evidence of early Permian A-type alkaline volcanism in the western Mongolian Altai
}

\author{
Vladimír ŽÁČEK ${ }^{*}$, David BURIÁNEK, Zoltán PÉCSKAY², Radek ŠKODA \\ ${ }^{1}$ Czech Geological Survey, Klárov 3, 11821 Prague 1, Czech Republic; vladimir.zacek@geology.cz \\ ${ }^{2}$ Institute for Nuclear Research, Hungarian Academy of Sciences (ATOMKI), Bem tér 18/c, Debrecen, Hungary \\ * Corresponding author
}

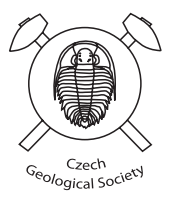

A dyke of alkali rhyolite intrudes the Tsetseg and Zuun Nuruu volcanosedimentary sequence of Ordovician-Silurian age (Hovd Zone, Central Asian Orogenic Belt) at the Botgon bag, Mankhan Soum, Hovd District in Western Mongolia. The rock consists of quartz and $\mathrm{K}$-feldspar phenocrysts set in fine-grained groundmass composed of quartz, $\mathrm{K}$-feldspar, albite, blue alkali amphibole (riebeckite-arfvedsonite containing up to $1.94 \mathrm{wt}$ \% $\mathrm{ZrO}_{2}$ ), tiny brown radial astrophyllite, annite and accessory zircon, ilmenite, fluorite, monazite, hematite, chevkinite and bastnäsite. Astrophyllite has unusual, highly ferroan composition and occurs as two sharply bound zones of astrophyllite I and II with the average empirical formulae: $\left(\mathrm{K}_{1.71} \mathrm{Na}_{0.01} \mathrm{Rb}_{0.08} \mathrm{Cs}_{0.01}\right)\left(\mathrm{Na}_{0.93} \mathrm{Ca}_{0.07}\right)\left(\mathrm{Fe}^{2+}{ }_{6.52} \mathrm{Mn}_{0.31} \mathrm{Zn}_{0.06}\right)\left(\mathrm{Ti}_{0.84} \mathrm{Zr}_{0.50} \mathrm{Nb}_{0.55}\right) \mathrm{Si}_{7.68} \mathrm{Al}_{0.32} \mathrm{O}_{26}(\mathrm{OH})_{3.78} \mathrm{~F}_{0.66}$ (astrophyllite I, $\mathrm{Zr}-\mathrm{Nb}$-rich); $\left(\mathrm{K}_{1.52} \mathrm{Rb}_{0.07}\right)\left(\mathrm{Na}_{0.81} \mathrm{Ca}_{0.19}\right)\left(\mathrm{Fe}^{2+}{ }_{6.31} \mathrm{Mn}_{0.28} \mathrm{Zn}_{0.06}\right)\left(\mathrm{Ti}_{1.28} \mathrm{Nb}_{0.30} \mathrm{Zr}_{0.28}\right) \mathrm{Si}_{7.68} \mathrm{Al}_{0.32} \mathrm{O}_{26}(\mathrm{OH})_{2.85} \mathrm{~F}_{0.67}$ (astrophyllite II). Geochemically, the rhyolite corresponds to strongly fractionated silicic alkaline A-type (ferroan) magmatic rock with 75.5-75.9 wt. $\% \mathrm{SiO}_{2}, 4.4$ wt. $\% \mathrm{~K}_{2} \mathrm{O}, 3.9-4.3$ wt. $\% \mathrm{Na}_{2} \mathrm{O}$ and $1.98-2.23$ wt. $\% \mathrm{Fe}_{2} \mathrm{O}_{3}{ }^{t}$, poor in $\mathrm{CaO}(0.26-0.37$ wt. \%), $\mathrm{MgO}$ (0.01-0.11 wt. \%), and $\mathrm{P}_{2} \mathrm{O}_{5}(0.01$ wt. \%). The rock is enriched in $\mathrm{Zr}, \mathrm{Nb}, \mathrm{Ta}, \mathrm{Ga}, \mathrm{Sn}, \mathrm{Y}, \mathrm{Rb}, \mathrm{Cs}, \mathrm{U}$ and Th, depleted in $\mathrm{V}, \mathrm{Sr}, \mathrm{Ba}, \mathrm{Sc}$, and exhibits a pronounced negative $\mathrm{Eu}$ anomaly $\left(\mathrm{Eu} / \mathrm{Eu}^{*}=0.03-0.05\right)$. The conventional whole-rock K-Ar geochronology yielded an age of 299.9 $\pm 9.1 \mathrm{Ma}(1 \sigma)$, which indicates latest Carboniferous or early Permian extension associated with the A-type alkaline volcanic activity.

Keywords: rhyolite, A-type, astrophyllite, $K$-Ar geochronology, $C A O B$

Received: 29 October, 2015; accepted: 12 January, 2016; handling editor: K. Schulmann

\section{Introduction}

The Central Asian Orogenic Belt (CAOB, Şengör et al. 1993; Jahn et al. 2000) is located between Uralian Orogen in the west, Siberian Craton in the north, Tarim Craton in the southwest and Sino-Korean Craton in the south. The CAOB represents the largest accretionary system on the Earth $(\sim 8000 \times 6000 \mathrm{~km})$ formed as a result of the subduction and closure of the Paleo-Asian Ocean (Zonenshain et al. 1990; Şengör et al. 1993; Jahn et al. 2000; Buslov et al. 2001). The CAOB is a complex "collage" of continental blocks, accretionary wedges, magmatic arcs, back-arcs and fragments of oceanic crust amalgamated during the Paleozoic to Mesozoic eras (Şengör et al. 1993).

The Late Paleozoic rift-related intrusive and extrusive acid igneous rocks are relatively common in northern China and south-western Mongolia (Wang ZG et al. 1993; Litvinovsky et al. 2002; Wu et al. 2002; Chen and Jahn 2004; Jahn 2004; Chen and Arakawa 2005; Wang Q et al. 2007; Buriánek et al. 2012; Liu et al. 2013; Mao et al. 2014). These generally undeformed, anorogenic-type intrusions provide evidence of the final amalgamation of terranes in this part of the CAOB (Jahn 2004; Liu et al. 2013; Mao et al. 2014).
This paper is intended to provide new geochemical and geochronological data on the astrophyllite- and alkali amphibole-bearing rhyolite dyke cutting the Lower Paleozoic volcanosedimentary and plutonic sequence in the Hovd Zone in Western Mongolia.

\section{Geological setting}

The study area is situated near the boundary between two terranes: (1) the Lake Zone to the east and (2) the Hovd Zone to the west (Badarch et al. 2002, Fig. 1). These domains are separated from each other by an important crustal-scale boundary, which was interpreted as a wide strike-slip fault zone (Tomurtogoo 1997).

The Lake Zone is a composite terrane, which contains Neoproterozoic to Cambrian volcanosedimentary complexes and ophiolites intruded by Late CambrianMiddle Ordovician syn- to post-tectonic gabbro, diorite, granodiorite and granite (Kovalenko et al. 1996; Kröner et al. 2010; Soejono et al. this volume). The Hovd Zone is interpreted as a part of the accretionary wedge (e.g., Xiao et al. 2004, details in Soejono et al. this volume) and is composed of several lithostratigraphic units of documented or supposed Ordovician to Silurian ages 


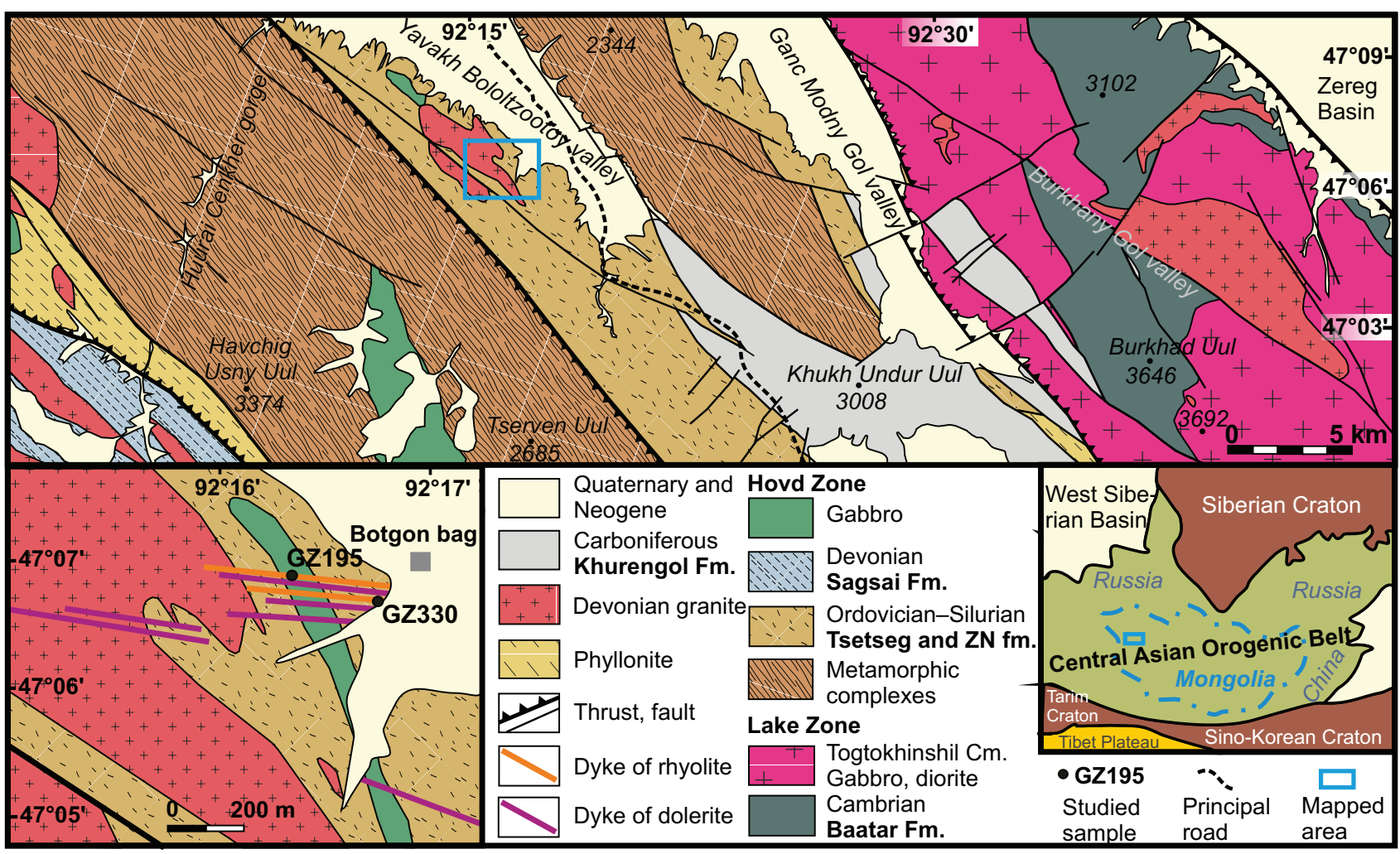

Fig. 1 Geological structure of the wider area around the alkali rhyolite occurrence depicted from recent (2015) manuscript geological maps 1:50 000 of the Czech Geological Survey. Abbreviations used: ZN - Zuun Nuruu, Cm. - Complex, Fm. - Formation.

(Baatarhuyag and Gansukh 1999). Also, the existing geochronological studies mostly from the Chinese Altai suggest these rocks to have been deposited during the Ordovician to the Silurian (Sun et al. 2008; Long et al. 2009). Lithologically, the Hovd Zone is composed mainly of pelitic schists intercalated with basic volcanic rocks and fossiliferous carbonate lenses. Greenschist- to amphibolite-facies metamorphism occurred during an Early Devonian event as shown by a study of zircon in the Habahe Group in the adjacent Tseel Terrane (Jiang et al. 2010, 2012). This sequence is crosscut by various granitic, dioritic to gabbroic intrusions, mostly synmetamorphic. Numerous $\mathrm{U}-\mathrm{Pb}$ zircon ages from similar calc-alkaline granitic rocks of the Habahe Group suggest Devonian to early Carboniferous age of the major magmatic pulse (Jiang et al. 2010). The youngest formation consists of Lower Carboniferous siliciclastic sediments deposited in a syn-orogenic basin.

\section{Methods}

\subsection{Field work}

Field work was carried out and relevant material and samples collected in June-July 2014, and 2015. During the field mapping, all important structural data were documented, and the KT-10 kappameter was used to measure the magnetic susceptibility.

\subsection{Whole-rock geochemistry}

The whole-rock analyses were performed in Activation Laboratories (Actlabs; Toronto, Canada) using the procedure 4Lithoresearch (http://www.actlabs.com). Major-element concentrations were obtained by inductively-coupled plasma optical emission spectrometry (ICP-OES), trace-element concentrations were established by inductively-coupled plasma mass spectrometry (ICP-MS). Subsequently, the sample GZ195 was analyzed in Laboratories of the Czech Geological Survey in Prague (using the material pulverized in the Actlabs) to determine $\mathrm{FeO}, \mathrm{Fe}_{2} \mathrm{O}_{3}, \mathrm{Li}_{2} \mathrm{O}$, and $\mathrm{F}$ (Tab. 1). Geochemical data were recalculated and plotted by the GCDkit software package (Janoušek et al. 2006).

\subsection{Electron microprobe analyses (EMPA)}

Electron-microprobe analyses of minerals (sample GZ195) were carried out using a Cameca SX-100 electron microprobe in the Joint laboratory of the Masaryk University and of the Czech Geological Survey in Brno. The astrophyllite and amphibole were 
Tab. 1 Whole-rock geochemical analyses of the alkali rhyolite (wt. \%,ppm)

\begin{tabular}{|c|c|c|c|c|c|}
\hline sample & GZ195 & GZ330 & sample & GZ195 & GZ330 \\
\hline $\mathrm{SiO}_{2}$ & 75.52 & 75.93 & $\mathrm{Fe}_{2} \mathrm{O}_{3}$ & 1.42 & - \\
\hline $\mathrm{Al}_{2} \mathrm{O}_{3}$ & 11.63 & 11.77 & $\mathrm{FeO}$ & 1.6 & - \\
\hline $\mathrm{Fe}_{2} \mathrm{O}_{3}{ }^{\mathrm{t}}$ & 1.98 & 2.23 & $\mathrm{Li}_{2} \mathrm{O}$ & 0.017 & - \\
\hline $\mathrm{MnO}$ & 0.029 & 0.034 & $\mathrm{~F}$ & 0.161 & - \\
\hline $\mathrm{MgO}$ & 0.11 & 0.01 & $\mathrm{Cs}$ & 6.2 & 4.7 \\
\hline $\mathrm{CaO}$ & 0.37 & 0.26 & $\mathrm{Rb}$ & 207 & 207 \\
\hline $\mathrm{Na}_{2} \mathrm{O}$ & 3.94 & 4.35 & $\mathrm{Sr}$ & 14 & 3 \\
\hline $\mathrm{K}_{2} \mathrm{O}$ & 4.49 & 4.43 & $\mathrm{Ba}$ & 40 & 11 \\
\hline $\mathrm{TiO}_{2}$ & 0.125 & 0.088 & $\mathrm{Be}$ & 9 & 9 \\
\hline $\mathrm{P}_{2} \mathrm{O}_{5}$ & 0.01 & $<0.01$ & $\mathrm{Th}$ & 23.8 & 18.9 \\
\hline LOI & 0.62 & 0.04 & $\mathrm{U}$ & 4.50 & 4.21 \\
\hline Total & 98.82 & 99.16 & $\mathrm{Zr}$ & 422 & 375 \\
\hline$\overline{\mathrm{A} / \mathrm{CNK}}$ & 0.97 & 0.95 & $\mathrm{Hf}$ & 14.0 & 10.9 \\
\hline $\mathrm{A} / \mathrm{NK}$ & 1.03 & 0.98 & $\mathrm{Nb}$ & 82.6 & 53.3 \\
\hline $\mathrm{Na}_{2} \mathrm{O} / \mathrm{K}_{2} \mathrm{O}$ & 0.88 & 0.98 & $\mathrm{Ta}$ & 7.61 & 6.12 \\
\hline $\bar{Y}$ & 92.6 & 109.0 & $\mathrm{~Pb}$ & 43 & 32 \\
\hline $\mathrm{La}$ & 37.0 & 39.6 & $\mathrm{Bi}$ & 0.2 & 0.2 \\
\hline $\mathrm{Ce}$ & 90.1 & 94.0 & $\mathrm{Ag}$ & 5.1 & 0.7 \\
\hline $\operatorname{Pr}$ & 10.9 & 11.3 & $\mathrm{Cu}$ & 20 & $<10$ \\
\hline $\mathrm{Nd}$ & 41.2 & 42.8 & $\mathrm{Zn}$ & 190 & 170 \\
\hline $\mathrm{Sm}$ & 11.8 & 12.4 & Mo & $<2$ & $<2$ \\
\hline $\mathrm{Eu}$ & 0.20 & 0.15 & As & 28 & $<5$ \\
\hline $\mathrm{Gd}$ & 12.8 & 14.4 & $\mathrm{Sn}$ & 18 & 11 \\
\hline $\mathrm{Tb}$ & 2.62 & 2.85 & V & 10 & $<5$ \\
\hline Dy & 16.6 & 18.7 & $\mathrm{Cr}$ & 90 & $<20$ \\
\hline Ho & 3.29 & 3.73 & $\mathrm{Co}$ & $<1$ & $<1$ \\
\hline $\mathrm{Er}$ & 9.98 & 11.2 & $\mathrm{Ni}$ & $<20$ & $<20$ \\
\hline $\mathrm{Tm}$ & 1.64 & 1.63 & $\mathrm{Sc}$ & $<1$ & $<1$ \\
\hline $\mathrm{Yb}$ & 10.4 & 10.6 & In & $<0.1$ & 0.1 \\
\hline $\mathrm{Lu}$ & 1.54 & 1.53 & $\mathrm{Sb}$ & 0.6 & $<0.2$ \\
\hline$\overline{\mathrm{Eu} / \mathrm{Eu}^{*}}$ & 0.05 & 0.03 & $\mathrm{Ga}$ & 36 & 32 \\
\hline $\mathrm{La}_{\mathrm{N} /} \mathrm{Yb}_{\mathrm{N}}$ & 2.4 & 2.5 & $\mathrm{Ge}$ & 2.9 & 2.4 \\
\hline $\mathrm{La}_{\mathrm{N}} / \mathrm{Sm}_{\mathrm{N}}$ & 2.0 & 2.3 & W & $<0.5$ & 1.2 \\
\hline$\Sigma \mathrm{REE}$ & 250.01 & 265.89 & $\mathrm{Tl}$ & 1.0 & 0.9 \\
\hline
\end{tabular}

measured at conditions: accelerating voltage $15 \mathrm{kV}$, beam current $10 \mathrm{nA}$ and beam diameter $8 \mu \mathrm{m}$. The following lines, monochromators and standards were used: F ( $\mathrm{K}_{a}, \mathrm{PC} 1$, topaz); $\mathrm{Si}, \mathrm{K}, \mathrm{Al}\left(\mathrm{K}_{\alpha}, \mathrm{TAP}\right.$, sanidine); $\mathrm{Mg}\left(\mathrm{K}_{\alpha}, \mathrm{TAP}\right.$, pyrope); $\mathrm{Na}\left(\mathrm{K}_{\alpha}, \mathrm{TAP}\right.$, albite); $\mathrm{Rb}$ ( $\mathrm{L}_{\alpha}, \mathrm{TAP}$, synthetic $\mathrm{Rb}$-leucite); $\mathrm{Zr}\left(\mathrm{L}_{\alpha}, \mathrm{TAP}\right.$, zircon); Ti (K, PET, anatase); Ca ( $\mathrm{K}, \mathrm{PET}$, wollastonite); $\mathrm{Cl}$ $\left(\mathrm{K}_{\alpha}, \mathrm{PET}\right.$, vanadinite); $\mathrm{Nb}\left(\mathrm{L}_{\alpha}, \mathrm{PET}\right.$, columbite-Fe); Cs (L $\alpha$, PET, pollucite); Fe (K, LIF, almandine); Mn $\left(\mathrm{K}_{\alpha}\right.$, LIF, spessartine); V ( $\left.\mathrm{K}_{\alpha}, \mathrm{LIF}, \mathrm{ScVO}_{4}\right)$; $\mathrm{Zn}\left(\mathrm{K}_{\alpha}\right.$, LIF, gahnite). Chromium, P, Y, La, Dy and $\mathrm{Yb}$ were sought but not detected. Peak-counting times were 10 and $20 \mathrm{~s}$ for major elements and 30 and $40 \mathrm{~s}$ for minor to trace elements. Raw intensities were processed by X-PHI matrix correction (Merlet 1994). Natural minerals and stable synthetic compounds were used for analyses of other minerals; beam diameter was $3 \mu \mathrm{m}$ for zircon and $5 \mu \mathrm{m}$ for other minerals.

\subsection{K-Ar geochronology}

The age determination was made by conventional $\mathrm{K}-\mathrm{Ar}$ method in ATOMKI, Debrecen, Hungary. Sample of rhyolite for the dating (GZ195) was prepared in the laboratories of the Czech Geological Survey in Prague. After the crushing, the whole-rock fraction of $0.125-0.30 \mathrm{~mm}$ $(50-100 \mathrm{~g})$ was washed several times in distilled water, and subsequently dried at $40^{\circ} \mathrm{C}$.

\subsubsection{Potassium determination}

Approximately $0.05 \mathrm{~g}$ of finely pulverized sample was digested in acids ( $\mathrm{HF}, \mathrm{HNO}_{3}$ and $\mathrm{H}_{2} \mathrm{SO}_{4}$ ) in Teflon beakers and finally dissolved in $0.2 \mathrm{M} \mathrm{HCl}$. Potassium was determined by flame photometry with a $\mathrm{Na}$ buffer and $\mathrm{Li}$ internal standard using Industrial M420 type flame photometer. Multiple runs of inter-laboratory standards (Asia1/95, LP-6, HD-B1, GL-0) indicated the accuracy and reproducibility of this method to be within $2 \%$.

\subsubsection{Argon measurements}

Approximately $0.5 \mathrm{~g}$ of the sample was wrapped in an aluminium foil and copper sieve preheated for about $24 \mathrm{~h}$ at $150-180^{\circ} \mathrm{C}$ in a vacuum. Argon was extracted under ultra-high vacuum conditions by RF (high frequency) induction heating and fusion of rock samples in Mo crucibles. The gas was purified by Ti sponge and SAES St 707 type getters to remove chemically active gas contaminants in addition to liquid nitrogen in cold trap to remove condensable gases. The extraction line is linked directly to a mass spectrometer $\left(90^{\circ}\right.$ magnetic sector, $155 \mathrm{~mm}$ radius, equipped with a Faraday cap), used in static mode.

Argon isotope ratios were measured by the ${ }^{38} \mathrm{Ar}$ isotope dilution mass spectrometric method, previously calibrated with atmospheric argon and international rock standards.

Experimental details and results of calibration have been described by Balogh (1985). The age of the samples is calculated using the decay constants suggested by Steiger and Jäger (1977). Analytical error is given at $68 \%$ confidence level $(1 \sigma)$ using the equation of Cox and Dalrymple (1967).

\section{Results}

\subsection{Field observations}

The rhyolite was sampled at two sites, both situated on the southern slope of a valley at the Botgon bag in Mankhan Soum, Hovd District in Western Mongo- 

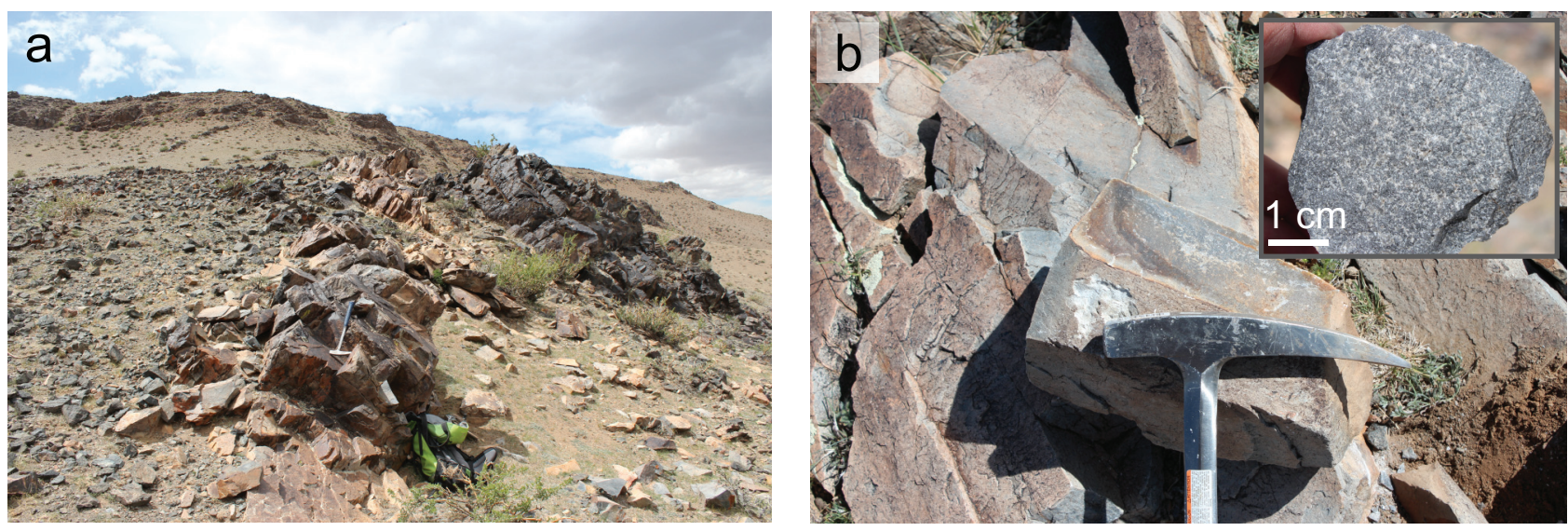

Fig. 2 Exposure of a rhyolite dyke at Botgon bag. a - Rhyolite dyke forms conspicuous, light-coloured rocky wall, and cuts the gabbro and quartzite schist of the Tsetseg and Zuun Nuruu formations of the Ordovician to Silurian ages (see Fig. 1). b - Sampling site and hand-specimen of sample GZ195.

lia. Samples GZ195 and GZ330 were taken from two individual WNW-ESE striking $\sim 2-5 \mathrm{~m}$ thick dykes, which cut with evident discordancy the gabbro, biotite schists, quartzite schists, quartzites, and porphyritic biotite granite (Fig. 2a). The schists, quartzite and gabbro belong to the Tsetseg and Zuun Nuruu formations of Silurian to Ordovician ages (Baatarhuyag and Gansukh 1999); the granite is likely of Devonian age. The studied rhyolite dykes are accompanied by a dyke swarm $300 \mathrm{~m}$ wide consisting of doleritic dykes up to $\sim 15 \mathrm{~m}$ thick, all of which show the same strike (Fig. 1). However, while the dolerite dykes are common and distributed over much of the area mapped, alkali rhyolite was observed only at the locality studied.

\subsection{Petrography}

The rhyolite is fresh, massive, greyish in colour, and contains quartz and feldspar phenocrysts visible to the eye, 1-3 mm long (Fig. 2). The rock displays low magnetic susceptibility of $0.03-0.20 \times 10^{-3}$ SI. In thin sections, a weak magmatic foliation is apparent (Fig. 3a). The mineral assemblage consists of quartz $+\mathrm{K}$-feldspar + albite with minor alkali amphibole (2-3 vol. \%), astrophyllite (1-2\%), annite $(\sim 1 \%)$ and several accessory minerals.

Under the microscope, the rock consists of perthitic microcline phenocrysts $1-3 \mathrm{~mm}$ long ( $\sim 3$ vol. \%), and minute quartz phenocrysts nearly $1 \mathrm{~mm}$ long $(\sim 5$ vol. \%). The groundmass (recrystallized glass, $\sim 80$ vol. \%) is composed of a granophyric intergrowth of alkali feldspar and quartz, $0.2-0.3 \mathrm{~mm}$ in size, along with minute grains of quartz (Fig $3 b$ ). Strongly pleochroic blue alkali amphibole forms $0.01-0.2 \mathrm{~mm}$ long prismatic to stubby aggregates (Fig. 3c). Bright brown astrophyllite clusters into radial aggregates composed of prismatic to acicular crystals up to $0.3 \mathrm{~mm}$ long (Fig. 3d). Greenish-black flakes of annite are prismatic to irregular, up to $0.5 \mathrm{~mm}$ long. Accessory minerals include abundant zircon, minor monazite and REE-rich fluorite as well as rare $\mathrm{Ca}, \mathrm{Fe}, \mathrm{Ti}$, Ce silicate, presumably chevkinite, and Ca-poor, F-rich, REE-bearing carbonate, possibly bastnäsite. Zircon forms euhedral stubby crystals or their angular fragments up to $\sim 100 \mu \mathrm{m}$ long. Monazite occurs as subhedral grains up to $\sim 60 \mu \mathrm{m}$, and ?chevkinite was found as single $10 \mu \mathrm{m}$ long inclusion in zircon. Inclusions of ?bastnäsite, $\sim 1-5$ $\mu \mathrm{m}$ across, and up to $25 \mu \mathrm{m}$ long inclusions of REE-rich fluorite in alkali amphibole were identified by EDX. Hematite was encountered in a unique miarolitic structure filled with quartz, annite and minor hematite, the latter forming $\sim 40 \mu \mathrm{m}$ hexagonal tabular crystals.

\subsection{Mineral chemistry}

Sodic amphibole shows weak irregular zoning apparent in BSE images (Fig. 3e); the zoning has a character of metasomatic replacement. The dominant darker and most probably older amphibole has low $\mathrm{Zr}$ content $(0.00-0.02$ apfu), whereas he lighter zones correspond to younger, $\mathrm{Zr}$-enriched compositions (0.05-0.22 apfu Zr). However, some intermediate compositions can be observed (Fig. 3e, Tab. 2). The sodic amphibole is Fe-dominant with low $\mathrm{Mn}(0.06-0.08 \mathrm{apfu}), \mathrm{Mg}(0.00-0.02 \mathrm{apfu})$, and Ti (0.02-0.12 apfu), see Tab. 2. The standard normalization procedures of EMPA data yielded non-stoichiometric formulae with $\mathrm{Si}=8.02-8.22 \mathrm{apfu}$, perhaps reflecting the possible presence of $\mathrm{Li}$ in the amphibole. Direct measurement of Li by LA ICP-MS was not possible due to small size of the amphiboles. The tentative formula calculated, assuming $\mathrm{Si}=8$ apfu, yielded a minimum $\mathrm{Li}_{2} \mathrm{O}$ content $0.03-0.6$ wt. \%, which corresponds to $0.02-0.42 \mathrm{Li}$ apfu (Tab. 2) The nomenclature of this alkali amphibole is therefore complicated due to variable $(\mathrm{Na}+\mathrm{K})_{\mathrm{A}}$ occupancies (0.27-0.66 apfu), and possible presence of Li. Principally, the amphibole composition varies between 

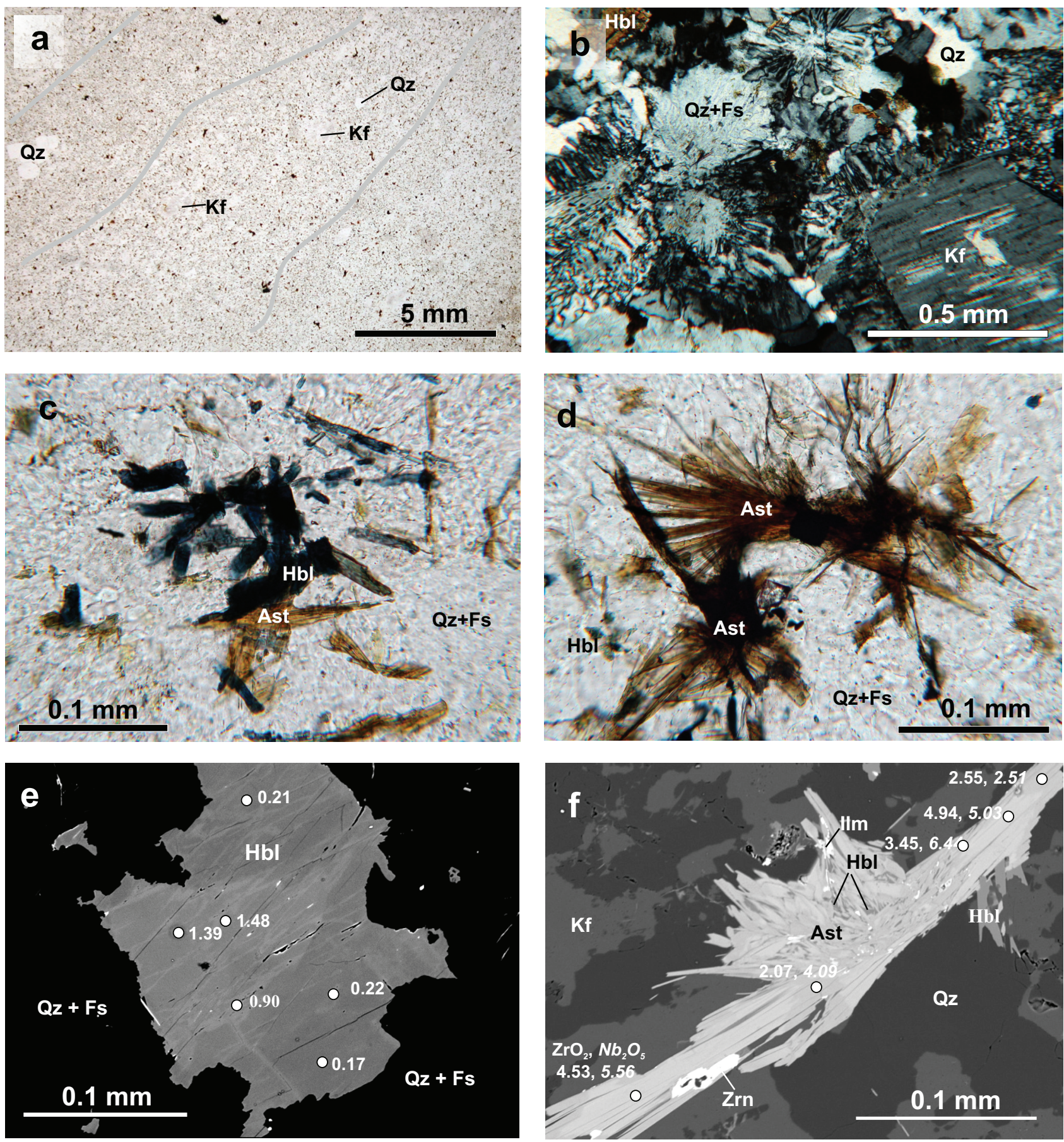

Fig. 3 Microscopic (a-d) and BSE images (e-f) of sample GZ195. a - Weak magmatic foliation (highlighted by grey lines) indicated by alternation of finer and coarser zones. The tiny semi-opaque inclusions are alkali amphibole, astrophyllite and annite (plane polarized light). b - Micrographic (granophyric) structure due to rapid cooling of the rhyolite melt (crossed nicols). $\mathbf{c}-$ A group of blue prismatic to stubby crystals of alkali amphibole associated with minor brownish prismatic to acicular crystals of astrophyllite (plane polarized light). d - Radial aggregates of acicular astrophyllite crystals associated with minor alkali amphibole. The associated minerals form intimate intergrowths of quartz and alkali feldspars (plane polarized light). $\mathbf{e}$ - Large corroded phenocryst of alkali amphibole with EMPA spots labelled by $\mathrm{ZrO}_{2}$ concentrations (wt. \%). The crystal of alkali amphibole displays zoning indicated by alternation of lighter streaks and patches, and relict darker domains. Lighter zones are strongly enriched in $\mathrm{Zr}$ (up to 1.48 wt. $\% \mathrm{ZrO}_{2}$ ), whereas dark domains contain only $\sim 0.20$ wt. $\% \mathrm{ZrO}_{2}$. Tiny white inclusions consist of REE-carbonate, possibly bastnäsite. f - Radial aggregate of astrophyllite with EMPA spots showing concentrations of $\mathrm{ZrO}_{2}$ and $\mathrm{Nb}_{2} \mathrm{O}_{5}$ (in italic) (both in wt. \%). Associated minerals include alkali amphibole, in places replaced by astrophyllite, quartz, potassium feldspar, and accessory ilmenite. The astrophyllite shows sector zoning, the darker zones represent mostly marginal parts of the crystals and have lower concentrations of both $\mathrm{Nb}$ and $\mathrm{Zr}$. Abbreviations used: $\mathrm{Hbl}$ - alkali amphibole, Ast - astrophyllite, Qz - quartz, Kf - potassium feldspar, Fs - alkali feldspars, Ilm - ilmenite, Zrn - zircon. 
Tab. 2 Chemical composition of alkali amphibole (wt. \%)

\begin{tabular}{|c|c|c|c|c|c|c|}
\hline zone & dark & dark & dark & light & light & light \\
\hline $\mathrm{SiO}_{2}$ & 51.72 & 50.93 & 51.00 & 50.36 & 50.42 & 51.17 \\
\hline $\mathrm{TiO}_{2}$ & 0.13 & 0.78 & 0.53 & 0.92 & 0.77 & 0.43 \\
\hline $\mathrm{ZrO}_{2}$ & 0.00 & 0.17 & 0.25 & 0.90 & 1.39 & 1.94 \\
\hline $\mathrm{Al}_{2} \mathrm{O}_{3}$ & 1.42 & 0.83 & 0.80 & 1.06 & 0.82 & 0.81 \\
\hline $\mathrm{Fe}_{2} \mathrm{O}_{3 \text { calc }}$ & 12.83 & 10.60 & 12.08 & 9.75 & 9.11 & 11.42 \\
\hline $\mathrm{FeO}_{\text {calc }}$ & 21.43 & 23.23 & 21.87 & 24.84 & 23.82 & 21.15 \\
\hline $\mathrm{MnO}$ & 0.51 & 0.51 & 0.44 & 0.43 & 0.60 & 0.51 \\
\hline $\mathrm{ZnO}$ & 0.30 & 0.61 & 0.53 & 0.59 & 0.60 & 0.42 \\
\hline $\mathrm{MgO}$ & 0.07 & 0.01 & 0.02 & 0.04 & 0.02 & 0.06 \\
\hline $\mathrm{CaO}$ & 0.14 & 0.14 & 0.16 & 0.17 & 0.15 & 0.15 \\
\hline $\mathrm{Li}_{2} \mathrm{O}_{\text {calc }}$ & 0.55 & 0.47 & 0.56 & 0.03 & 0.38 & 0.66 \\
\hline $\mathrm{Na}_{2} \mathrm{O}$ & 7.49 & 7.86 & 7.48 & 6.50 & 7.51 & 7.11 \\
\hline $\mathrm{K}_{2} \mathrm{O}$ & 1.36 & 1.21 & 1.42 & 1.15 & 1.20 & 1.61 \\
\hline $\mathrm{F}$ & 1.57 & 2.02 & 1.63 & 0.64 & 1.85 & 1.85 \\
\hline $\mathrm{H}_{2} \mathrm{O}_{\text {calc }}$ & 1.19 & 0.95 & 1.15 & 1.61 & 1.03 & 1.04 \\
\hline$-\mathrm{O}=\mathrm{F}$ & -0.66 & -0.85 & -0.69 & -0.27 & -0.78 & -0.78 \\
\hline total & 100.71 & 100.32 & 99.92 & 98.99 & 99.67 & 100.33 \\
\hline $\mathrm{Si}$ & 8.000 & 8.000 & 8.000 & 8.000 & 8.000 & 8.000 \\
\hline $\mathrm{Ti}$ & 0.016 & 0.092 & 0.063 & 0.110 & 0.092 & 0.050 \\
\hline $\mathrm{Zr}$ & 0.000 & 0.013 & 0.019 & 0.070 & 0.107 & 0.148 \\
\hline $\mathrm{Al}$ & 0.258 & 0.153 & 0.147 & 0.199 & 0.152 & 0.149 \\
\hline $\mathrm{Fe}^{3+}$ & 1.494 & 1.252 & 1.428 & 1.165 & 1.088 & 1.342 \\
\hline $\mathrm{Zn}$ & 0.035 & 0.071 & 0.061 & 0.069 & 0.070 & 0.048 \\
\hline $\mathrm{Mn}^{2+}$ & 0.066 & 0.068 & 0.058 & 0.058 & 0.081 & 0.067 \\
\hline $\mathrm{Fe}^{2+}$ & 2.772 & 3.051 & 2.868 & 3.300 & 3.160 & 2.767 \\
\hline $\mathrm{Mg}$ & 0.016 & 0.002 & 0.006 & 0.009 & 0.004 & 0.014 \\
\hline $\mathrm{Li}$ & 0.344 & 0.297 & 0.350 & 0.019 & 0.244 & 0.415 \\
\hline C subtotal & 5.001 & 4.999 & 5.000 & 4.999 & 4.998 & 5.000 \\
\hline $\mathrm{Ca}$ & 0.023 & 0.023 & 0.027 & 0.029 & 0.025 & 0.025 \\
\hline $\mathrm{Na}$ & 1.977 & 1.977 & 1.973 & 1.971 & 1.975 & 1.975 \\
\hline B subtotal & 2.000 & 2.000 & 2.000 & 2.000 & 2.000 & 2.000 \\
\hline $\mathrm{Na}$ & 0.269 & 0.415 & 0.300 & 0.032 & 0.335 & 0.181 \\
\hline K & 0.269 & 0.243 & 0.284 & 0.233 & 0.244 & 0.322 \\
\hline A subtotal & 0.538 & 0.658 & 0.584 & 0.265 & 0.579 & 0.503 \\
\hline $\mathrm{O}$ & 22.000 & 22.000 & 22.000 & 22.000 & 22.000 & 22.000 \\
\hline $\mathrm{OH}$ & 1.232 & 0.995 & 1.190 & 1.681 & 1.073 & 1.084 \\
\hline $\mathrm{F}$ & 0.768 & 1.005 & 0.810 & 0.319 & 0.927 & 0.916 \\
\hline
\end{tabular}

normalization scheme based on $22 \mathrm{O}, 2(\mathrm{OH}+\mathrm{F}), T+C=13$

$\mathrm{Li}$ calculated for $8 \mathrm{Si}$ apfu showing the minimum content of $\mathrm{Li}$ in the formula
(2000) also stated that the $\mathrm{Fe}^{3+} / \mathrm{Fe}^{t}$ values are low, and following the Mössbauer spectroscopy range from $0.01-0.21$, corresponding to $0.05-0.56$ apfu $\mathrm{Fe}^{3+}$. Therefore, all iron is considered here to be $\mathrm{Fe}^{2+}$.

Astrophyllite (both I and II) exhibits an atypical chemical composition. It is classified as astrophyllite on the basis of prevailing cation at $C$-site ( $\mathrm{Fe})$, but with high $\mathrm{Fe}_{\text {tot }} /\left(\mathrm{Fe}_{\text {tot }}+\mathrm{Mn}\right)$ ratio of $0.95-0.96$ (Fig. 4a). The contents of $\mathrm{Nb}$ and $\mathrm{Zr}$ are also elevated, so that in the diagram depicting the astrophyllite group based on $D$-site occupancy, the compositions of astrophyllite I are plotted in the proximity of "Fe-zircophyllite" and niobophyllite fields (Fig. 4b) (Kapustin 1972; Piilonen et al. 2000, 2003; Sokolova 2012, see also Tab. 3).

The resulting average empirical formula of astrophyllite I ( $\mathrm{Zr}-\mathrm{Nb}$-rich) corresponds to: $\left(\mathrm{K}_{1.71} \mathrm{Na}_{0.01} \mathrm{Rb}_{0.08} \mathrm{Cs}_{0.01}\right)\left(\mathrm{Na}_{0.93} \mathrm{Ca}_{0.07}\right)$ $\left(\mathrm{Fe}^{2+}{ }_{6.52} \mathrm{Mn}_{0.31} \mathrm{Zn}_{0.06}\right)\left(\mathrm{Ti}_{0.84} \mathrm{Zr}_{0.50} \mathrm{Nb}_{0.55}\right)$ $\mathrm{Si}_{7.68} \mathrm{Al}_{0.32} \mathrm{O}_{26}(\mathrm{OH})_{3.78} \mathrm{~F}_{0.66}$. In comparison, the average formula of astrophyllite II is: $\left(\mathrm{K}_{1.52} \mathrm{Rb}_{0.07}\right)\left(\mathrm{Na}_{0.81} \mathrm{Ca}_{0.19}\right)\left(\mathrm{Fe}^{2+}{ }_{6.31}\right.$ $\left.\mathrm{Mn}_{0.28} \mathrm{Zn}_{0.06}\right)\left(\mathrm{Ti}_{1.28} \mathrm{Nb}_{0.30} \mathrm{Zr}_{0.28}\right) \mathrm{Si}_{7.68} \mathrm{Al}_{0.32}$ $\mathrm{O}_{26}(\mathrm{OH})_{2.85} \mathrm{~F}_{0.67}$.

Annite has a composition close to the end-member formula, slightly enriched in $\mathrm{Rb}$ and $\mathrm{Zn}$ : $\left(\mathrm{K}_{1.01} \mathrm{Na}_{0.02} \mathrm{Rb}_{0.02}\right)$ $\left(\mathrm{Fe}^{2+}{ }_{2.11} \mathrm{Mg}_{0.03} \mathrm{Mn}_{0.03} \mathrm{Zn}_{0.04}\right) \quad \mathrm{Al}_{1.06} \mathrm{Si}_{3.41}$ $\mathrm{OH}_{1.16} \mathrm{~F}_{0.84}$. The mica is purely ferroan, $\mathrm{Mg} /\left(\mathrm{Mg}+\mathrm{Fe}^{\mathrm{t}}\right)=0.016$. The phenocrysts of potassium feldspar $\left(\mathrm{Or}_{98} \mathrm{Ab}_{2}\right)$ contain $\sim 0.1$ wt. $\% \mathrm{FeO}$, whereas the groundmass $\mathrm{K}$-feldspar $\left(\mathrm{Or}_{98} \mathrm{Ab}_{2}\right)$ is slightly richer in this oxide $(0.31-0.39$ wt. \% $\mathrm{FeO}$ ). Plagioclase is represented by albite $\left(\mathrm{Ab}_{95} \mathrm{Or}_{5}\right)$ slightly enriched in $\mathrm{FeO}$ riebeckite (which has theoretically $(\mathrm{Na}+\mathrm{K})_{\mathrm{A}}=0$ apfu) and arfvedsonite (with theoretical $(\mathrm{Na}+\mathrm{K})_{\mathrm{A}}=1.0 \mathrm{apfu}$ ). Nevertheless, if Li exceeds $0.5 \mathrm{apfu}$, then the amphibole should be classed as ferroleakeite.

Astrophyllite shows a sharp sector- to patchy growth zoning in the BSE image. The lighter sectors (astrophyllite I) are significantly richer both in $\mathrm{Zr}$ and $\mathrm{Nb}$ than the darker ones that are mostly marginal (astrophyllite II, Fig. 3f). A proportion of $31(\mathrm{O}+\mathrm{OH}+\mathrm{F})$ assuming 5 atoms of $(\mathrm{OH}+\mathrm{F})$ was used for calculation of astrophyllite formula. A general empirical formula proposed by Piilonen et al. (2000): $A_{2} B C_{7} D_{2} T_{8} \mathrm{O}_{26}(\mathrm{OH})_{4} X$ was applied, where $A=\mathrm{K}, \mathrm{Na}, \mathrm{Rb}, \mathrm{Cs} ; B=\mathrm{Na}, \mathrm{Ca} ; C=\mathrm{Fe}^{2+}, \mathrm{Fe}^{3+}, \mathrm{Mn}, \mathrm{Mg}$, $\mathrm{Zn} ; D=\mathrm{Ti}, \mathrm{Nb}, \mathrm{Zr} ; T=\mathrm{Si}$, and $X=\mathrm{F}, \mathrm{OH}$. Piilonen et al.
$(0.39 \%)$, and $\mathrm{Rb}_{2} \mathrm{O}(0.11$ wt. \%). The concentrations of oxides of $\mathrm{Ba}, \mathrm{Sr}, \mathrm{Cs}$, and $\mathrm{P}$ are below 0.02 wt. \% in all feldspars.

Zircon contains elevated Th $(0.012-0.035 \mathrm{apfu}), \mathrm{U}$ (0.003-0.007 apfu), Y (0.011-0.034 apfu), moderate Hf (0.013-0.014 apfu) and $\Sigma$ REE (0.018-0.032 apfu).

\subsection{Whole-rock geochemistry}

The rhyolite $\left(\mathrm{SiO}_{2}=75.52\right.$ and 75.93 wt. \%) is ferroan $\left(\mathrm{FeO}^{t} /\left(\mathrm{FeO}^{\mathrm{t}}+\mathrm{MgO}\right)=0.94-1.00\right.$ by weight; Fig. 5a), alkali-calcic $\left(\mathrm{Na}_{2} \mathrm{O}+\mathrm{K}_{2} \mathrm{O}-\mathrm{CaO}=8.06-8.52\right.$ wt. \%; Fig. $5 \mathrm{~b})$, and metaluminous ( $\mathrm{A} / \mathrm{CNK}=0.81-0.97)$, with 
(a)

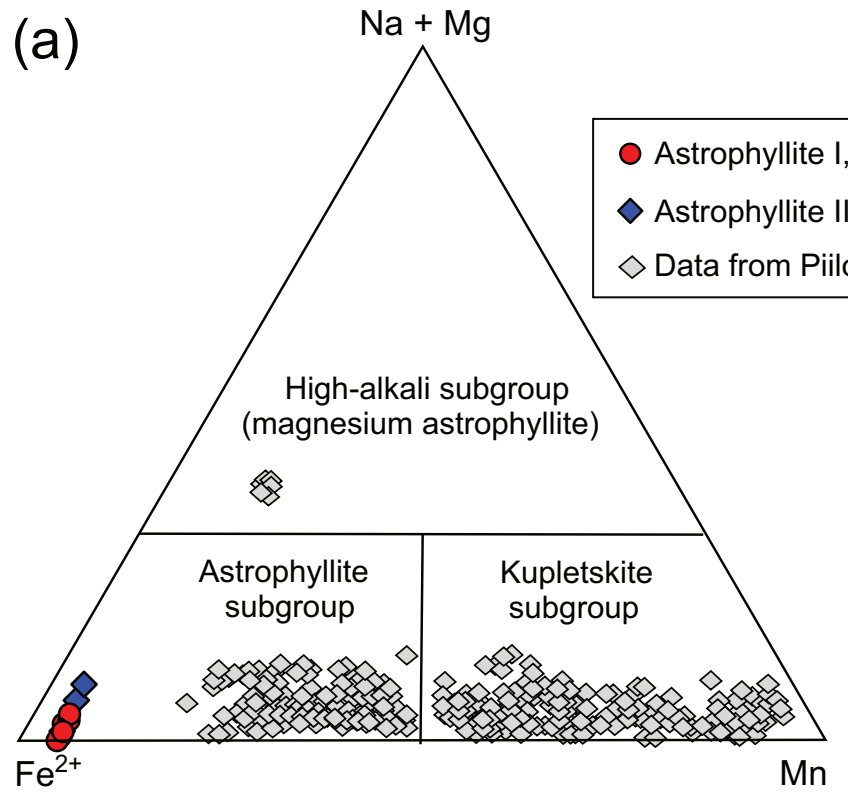

(b)

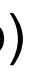

Ti

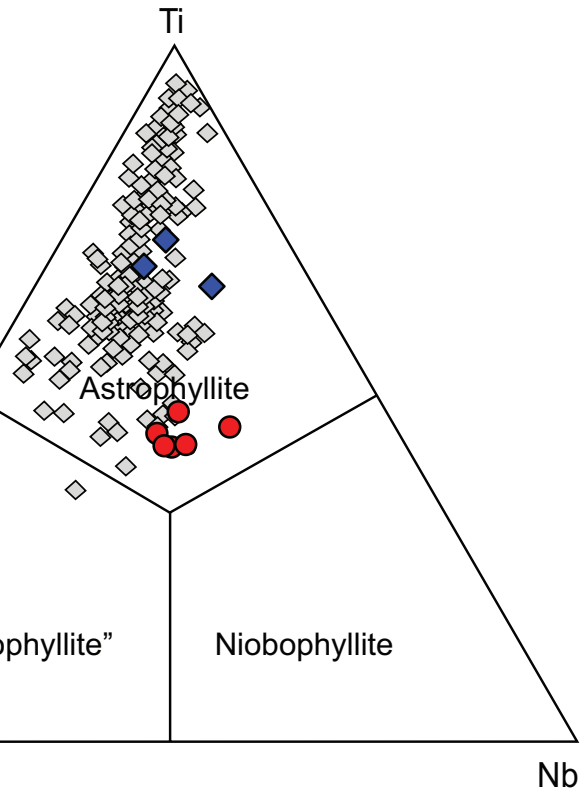

Fig. 4 Chemical composition of astrophyllite from the Botgon bag, Mongolia, compared with 695 EMP compositions reported by Piilonen et al. (2000). a - Ternary $C$-site $\mathrm{Fe}^{2+}-(\mathrm{Na}+\mathrm{Mg})-\mathrm{Mn}$ classification diagram. b - Ternary $D$-site $\mathrm{Zr}-\mathrm{Ti}-\mathrm{Nb}$ classification diagram for minerals of the astrophyllite group (both diagrams after Piilonen et al. 2000). Note the anomalous, extremely ferroan composition of astrophyllite in Fig. 4a, and the $\mathrm{Zr}+\mathrm{Nb}$ enrichment in astrophyllite I (Fig. 4b).

a low $\mathrm{MgO}$ content $(0.01-0.11$ wt. \%). The rhyolite is enriched in most of the LILE (e. g. Rb, K), HFSE (e. g. $\mathrm{Th}, \mathrm{Zr}, \mathrm{Nb}, \mathrm{Ta}$ ) and depleted in $\mathrm{Ba}, \mathrm{P}, \mathrm{Sr}$ and $\mathrm{Ti}$ when observed on the primitive mantle-normalized multielement pattern (McDonough and Sun 1995; Fig. 6a). The chondrite-normalized REE pattern (Fig. 6b) shows higher proportion of LREE over $\operatorname{HREE}\left(\mathrm{La}_{\mathrm{N}} / \mathrm{Yb}_{\mathrm{N}}=\right.$ 2.40-2.52), pronounced negative $\mathrm{Eu}$ anomaly ( $\mathrm{Eu} / \mathrm{Eu}^{*}$ $=0.03-0.05)$ and a M-type tetrad effect $\left(\mathrm{TE}_{1-3}=1.13-\right.$ 1.14; the degree of the lanthanide tetrad effect sensu Irber 1999).

The relatively high content of $\mathrm{Zr}$ (375-422 ppm), Nb (53-82 ppm), Ce (90-94 ppm; Fig. 7a), and Y (93-109 ppm; Fig. $7 b$ ), as well as the elevated $10000 \times \mathrm{Ga} / \mathrm{Al}$ ratios of 5.1 and 5.8 indicate an A-type affinity for the rhyolite (Whalen 1987; Bonin 2008).

In the diagram $\left(\mathrm{Na}_{2} \mathrm{O}+\mathrm{K}_{2} \mathrm{O}\right)$ $-\mathrm{Fe}_{2} \mathrm{O}_{3}{ }^{\mathrm{t}} \times 5-(\mathrm{CaO}+\mathrm{MgO}) \times$ 5 (Fig. 7c) for classification of the A-type (ferroan) granites (Grebennikov 2014), the rhyolite falls along the boundary between the field of $\mathrm{A}_{1}$-type granite (silicic rocks of within-plate geodynamic settings: ocean islands and continental rifts)

Fig. 5 Whole-rock geochemical discrimination diagrams. a $-\mathrm{FeO}^{t} /\left(\mathrm{FeO}^{t}\right.$ $+\mathrm{MgO})$ vs. $\mathrm{SiO}_{2} . \mathbf{b}-\left(\mathrm{Na}_{2} \mathrm{O}+\mathrm{K}_{2} \mathrm{O}-\right.$ $\mathrm{CaO}$ ) vs. $\mathrm{SiO}_{2}$ (Frost et al. 2001).
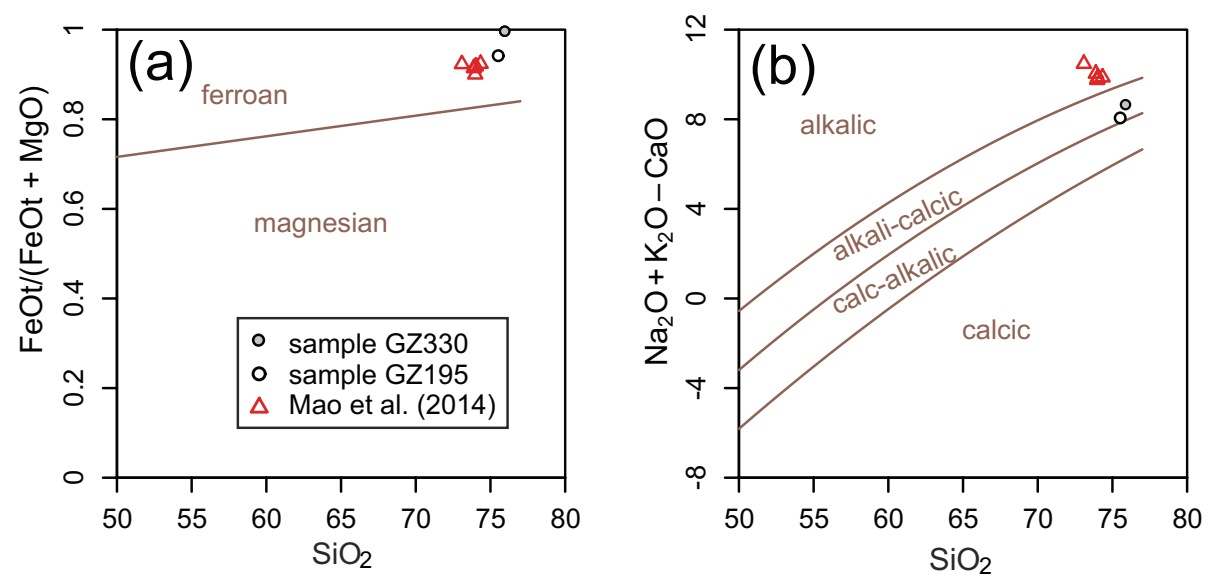
Tab. 3 Chemical composition of astrophyllite (wt. \%), normalization scheme based on $26 \mathrm{O}, 5(\mathrm{OH}+\mathrm{F})$

\begin{tabular}{|c|c|c|c|c|c|}
\hline & I & I & I & II & II \\
\hline $\mathrm{Nb}_{2} \mathrm{O}_{5}$ & 6.44 & 5.32 & 4.76 & 2.51 & 4.09 \\
\hline $\mathrm{SiO}_{2}$ & 33.61 & 33.88 & 33.65 & 34.90 & 34.63 \\
\hline $\mathrm{TiO}_{2}$ & 5.10 & 4.74 & 4.90 & 8.22 & 7.24 \\
\hline $\mathrm{ZrO}_{2}$ & 3.45 & 4.90 & 5.00 & 2.55 & 2.07 \\
\hline $\mathrm{Al}_{2} \mathrm{O}_{3}$ & 1.35 & 1.24 & 1.10 & 0.97 & 1.17 \\
\hline $\mathrm{V}_{2} \mathrm{O}_{3}$ & 0.03 & 0.02 & 0.04 & 0.06 & 0.05 \\
\hline $\mathrm{Cr}_{2} \mathrm{O}_{3}$ & 0.01 & 0.01 & 0.01 & 0.00 & 0.00 \\
\hline $\mathrm{MgO}$ & 0.02 & 0.00 & 0.01 & 0.01 & 0.01 \\
\hline $\mathrm{CaO}$ & 0.24 & 0.24 & 0.45 & 0.69 & 0.36 \\
\hline $\mathrm{MnO}$ & 1.66 & 1.50 & 1.46 & 1.46 & 1.63 \\
\hline $\mathrm{FeO}^{\mathrm{t}}$ & 34.57 & 33.84 & 33.93 & 33.79 & 35.16 \\
\hline $\mathrm{ZnO}$ & 0.36 & 0.28 & 0.34 & 0.32 & 0.41 \\
\hline $\mathrm{Na}_{2} \mathrm{O}$ & 2.01 & 2.18 & 2.11 & 2.00 & 2.14 \\
\hline $\mathrm{K}_{2} \mathrm{O}$ & 5.82 & 5.78 & 6.03 & 5.48 & 5.55 \\
\hline $\mathrm{Rb}_{2} \mathrm{O}$ & 0.60 & 0.55 & 0.59 & 0.47 & 0.53 \\
\hline $\mathrm{Cs}_{2} \mathrm{O}$ & 0.11 & 0.06 & 0.08 & 0.05 & 0.03 \\
\hline $\mathrm{F}$ & 0.89 & 0.91 & 0.92 & 1.06 & 0.97 \\
\hline $\mathrm{Cl}$ & 0.02 & 0.00 & 0.02 & 0.00 & 0.02 \\
\hline $\mathrm{H}_{2} \mathrm{O}$ & 2.66 & 2.28 & 2.49 & 1.94 & 2.27 \\
\hline$-\mathrm{O}=\mathrm{F}$ & 0.38 & 0.38 & 0.39 & 0.45 & 0.41 \\
\hline Total & 98.56 & 97.36 & 97.47 & 96.03 & 97.93 \\
\hline $\mathrm{Nb}$ & 0.662 & 0.545 & 0.492 & 0.252 & 0.410 \\
\hline $\mathrm{Si}$ & 7.640 & 7.668 & 7.704 & 7.745 & 7.693 \\
\hline $\mathrm{Ti}$ & 0.872 & 0.807 & 0.845 & 1.372 & 1.210 \\
\hline $\mathrm{Zr}$ & 0.383 & 0.541 & 0.558 & 0.276 & 0.224 \\
\hline $\mathrm{A} 1$ & 0.360 & 0.332 & 0.296 & 0.255 & 0.307 \\
\hline V & 0.005 & 0.003 & 0.008 & 0.011 & 0.009 \\
\hline $\mathrm{Cr}$ & 0.002 & 0.002 & 0.001 & 0.000 & 0.000 \\
\hline $\mathrm{Mg}$ & 0.008 & 0.000 & 0.002 & 0.003 & 0.004 \\
\hline $\mathrm{Ca}$ & 0.058 & 0.057 & 0.110 & 0.164 & 0.086 \\
\hline Mn & 0.320 & 0.287 & 0.282 & 0.274 & 0.307 \\
\hline $\mathrm{Fe}$ & 6.572 & 6.406 & 6.497 & 6.272 & 6.530 \\
\hline $\mathrm{Zn}$ & 0.061 & 0.047 & 0.057 & 0.052 & 0.068 \\
\hline $\mathrm{Na}$ & 0.885 & 0.958 & 0.936 & 0.859 & 0.921 \\
\hline K & 1.687 & 1.670 & 1.762 & 1.550 & 1.573 \\
\hline $\mathrm{Rb}$ & 0.087 & 0.080 & 0.087 & 0.067 & 0.075 \\
\hline $\mathrm{Cs}$ & 0.011 & 0.006 & 0.008 & 0.005 & 0.003 \\
\hline Total & 19.613 & 19.408 & 19.645 & 19.158 & 19.422 \\
\hline $\mathrm{F}$ & 0.640 & 0.654 & 0.663 & 0.746 & 0.679 \\
\hline $\mathrm{Cl}$ & 0.007 & 0.000 & 0.007 & 0.000 & 0.008 \\
\hline $\mathrm{OH}$ & 4.028 & 3.438 & 3.796 & 2.865 & 3.359 \\
\hline $\mathrm{O}$ & 26 & 26 & 26 & 26 & 26 \\
\hline $\mathrm{Fe} /(\mathrm{Fe}+\mathrm{Mn})$ & 0.954 & 0.957 & 0.958 & 0.958 & 0.955 \\
\hline
\end{tabular}

\section{5. $K$-Ar dating}

The studied sample (rhyolite GZ195) yielded an age of $299.9 \pm 9.1 \mathrm{Ma}(1 \sigma)$, which falls close to the Carbonifer-
ous/Permian boundary (see Tab 4). Since this rhyolitic dyke does not exhibit any significant alteration, and forms a small intrusive body, the established $\mathrm{K}-\mathrm{Ar}$ age should be considered the emplacement age.

\section{Discussion and conclusions}

The results of detailed study show that the rhyolite has an anomalous mineralogy with regard to the occurrence of Zr-rich alkali amphibole (riebeckite-arfvedsonite, possibly ferroleakeite) and astrophyllite. Astrophyllite has extremely high $\mathrm{Fe}^{t} /\left(\mathrm{Fe}^{\mathrm{t}}+\mathrm{Mn}\right.$ ) ratio of $0.95-0.96$ (Fig. 4), not yet reported in minerals of the astrophyllite group (cf. Piilonen et al. 2000, 2003).

The geological position and chemical composition of the studied rhyolite dyke (ferroan alkali-calcic metaluminous rhyolite) are consistent with post-collisional geodynamic settings described in literature (e.g. Sylvester 1989). Following the classification of A-type granites of Grebennikov (2014), and considering a scheme of the origin of A-type granitoids suggested by Frost and Frost (2011), the rhyolite studied shows features transitional between the $\mathrm{A}_{1}$-type and $\mathrm{A}_{2}$-type granites. The relatively low $\mathrm{Y} / \mathrm{Nb}$ ratios of 1.1 and 2.1, and high $\mathrm{Cr}$ contents (up to $90 \mathrm{ppm}$ ) indicate that the rock may represent a differentiate of a mantle-derived, alkali basalt magma (e.g. Eby 1992; Frost and Frost 2011). As shown by Eby (1992), crustal contamination of $\mathrm{A}_{1}$ group granitic magmas may increase $\mathrm{Y} / \mathrm{Nb}$ ratio so that it plots in the $\mathrm{A}_{2}$ field.

The negative $\mathrm{Ti}, \mathrm{Ba}, \mathrm{Sr}, \mathrm{P}$ and $\mathrm{Eu}$ anomalies in the multielement plot (Fig. 6a) can be interpreted as a result of fractionation of feldspars, apatite and Ti-rich minerals. The lanthanide tetrad effect is usually reported from highly evolved granites (Bau 1996) and indicates a fluid/ melt interaction within this system (Irber 1999). According to Yang et al. (2014), formation of hydrothermal and metamict zircons can be responsible for the origin of the M-type tetrad effect. Fluid interaction in the late- or post-magmatic phase is also supported by secondary enrichment of the alkali amphibole with Zr. Increased oxygen fugacity during the terminal phases of hydrothermal process is indicated by crystallization of hematite in miarolitic cavities, whereas the rock itself contains accessory ilmenite.

The conventional $\mathrm{K}-\mathrm{Ar}$ geochronology of the sample studied yielded 299.9 $\pm 9.1 \mathrm{Ma}$, indicating latest Carboniferous or Early Permian igneous activity. A recently studied Early Permian peralkaline rhyolite from southern Altaids exhibits similar petrology, chemical composition and tectonic setting, and a very 

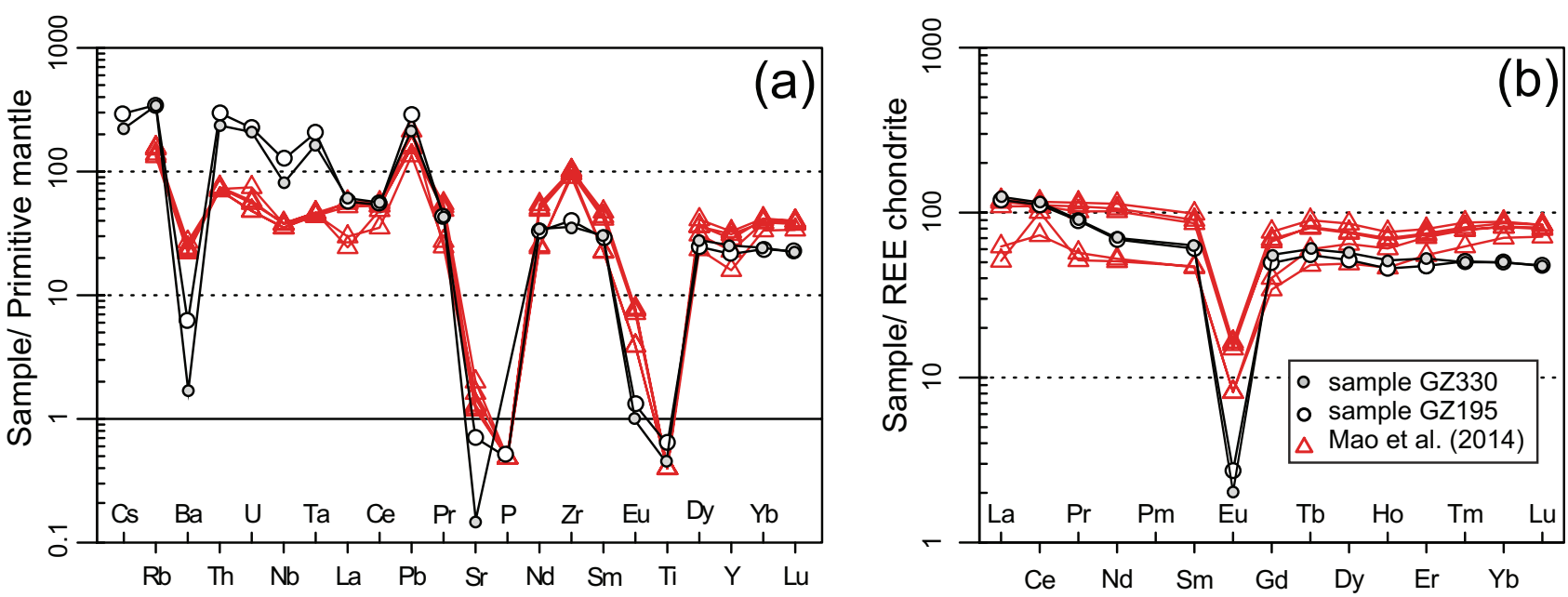

Fig. 6 Multi-element diagrams. a - Primitive mantle normalized pattern. b - Chondrite-normalized REE pattern. Normalizing values are taken from McDonough and Sun (1995) and Boynton (1984), respectively.

similar age $(286.5 \pm 2.1$ and $286.7 \pm 2.1 \mathrm{Ma}-$ Mao et al. 2014).

The presence of $A_{1}$-type volcanism gives evidence of early Permian extension in the western Mongolian Altai, which can be related to initial rifting (see. e.g. Eby 1992; Bonin 2007).

Acknowledgments. This study was supported by the Czech Development Agency project "Geological mapping 1:50 000 and assessment of economic potential of selected region in Western Mongolia" CzDA-ROMN-2013-1-32220. The authors are grateful to Pavel Čáp, Tomáš Vorel, Igor Soejono, Kryštof Verner, Bayart Nadmid and Soyol-Erdene Ulziisuren for invaluable field assistance, to Stanislav Vrána for microscopic studies of rocks and to Vladislav Rapprich for his assistance in

Fig. 7 Whole-rock geochemical discrimination diagrams. Ce (a) and $\mathrm{Y}$ (b) vs. $10000 \times \mathrm{Ga} / \mathrm{Al}$ after Whalen et al. (1987), showing the fields of I-, S-, and A-type granites. $\mathbf{c}-$ Ternary plot $\mathrm{Fe}_{2} \mathrm{O}_{3}{ }^{\mathrm{t}} \times 5-\left(\mathrm{Na}_{2} \mathrm{O}+\mathrm{K}_{2} \mathrm{O}\right)-(\mathrm{CaO}+$ $\mathrm{MgO}) \times 5$ for classification of A-type (ferroan) granites, (after Grebennikov 2014). d - Ternary plot $\mathrm{Y}-\mathrm{Nb}-3 \times$ Ga for classification of A-type granites (Eby 1992) sample preparation for $\mathrm{K}-\mathrm{Ar}$ geochronology. The authors are also grateful to reviewers Paula Piilonen and Elena Sokolova and to chief editor Vojtěch Janoušek for suggested improvements and to Jaroslav Hak for the correction of the language.

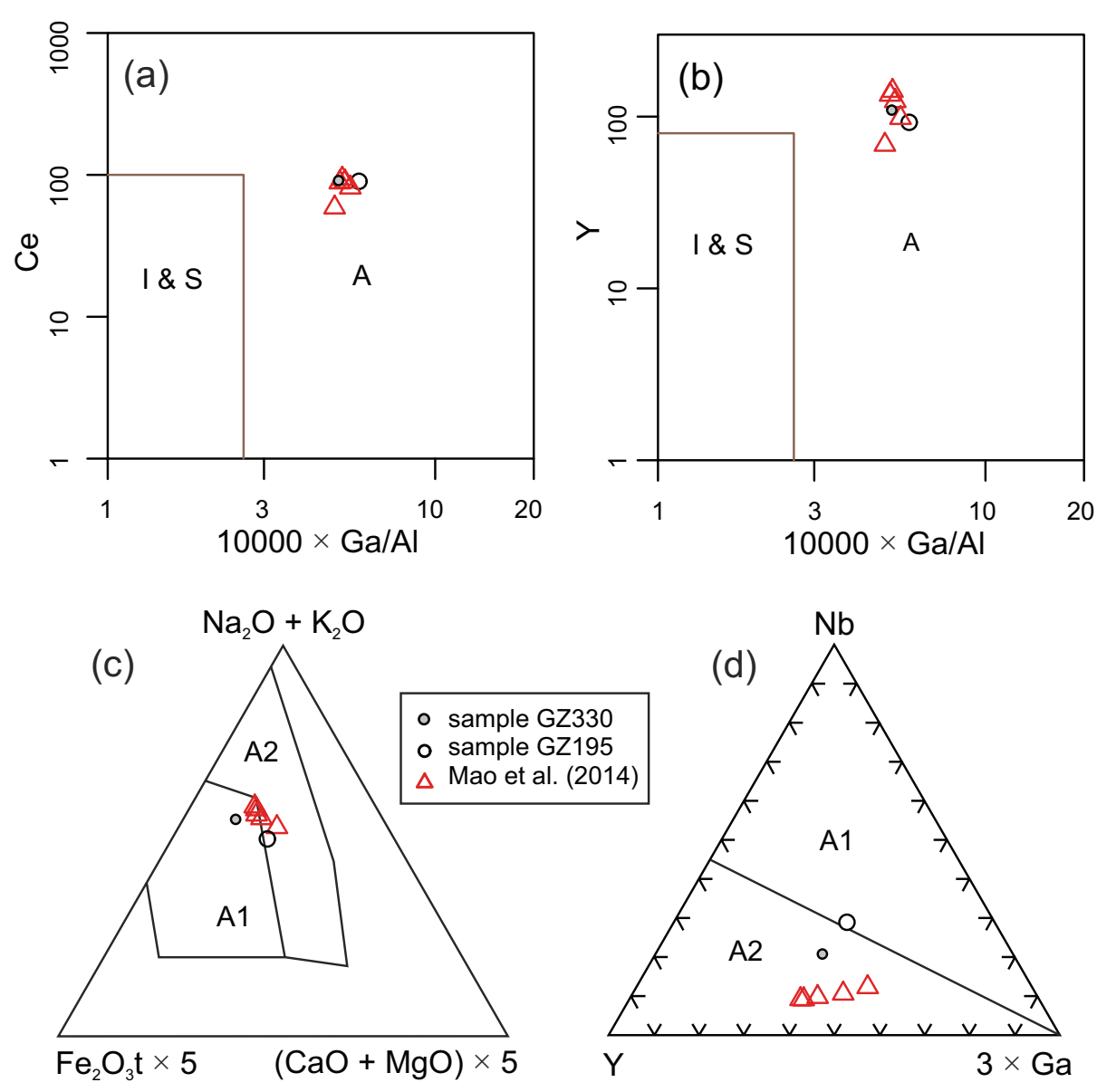




\section{References}

Battarhuyag A, Gansukh L (1999) Geological map 1 : 200 000, L-46-IX, L-46-II-G. Unpublished Manuscript, Geofond, Ulaanbaatar

Badarch G, Cunningham CW, Windley BF (2002) A new terrane subdivision for Mongolia: implications for the Phanerozoic crustal growth of Central Asia. J Asian Earth Sci 21: 87-110

BALOGH K (1985) K/Ar dating of Neogene volcanic activity in Hungary: experimental technique, experiences and methods of chronologic studies. ATOMKI Rep. D/1: 277-288

BAU M (1996) Controls on the fractionation of isovalent trace elements in magmatic and aqueous systems: evidence from $\mathrm{Y} / \mathrm{Ho}, \mathrm{Zr} / \mathrm{Hf}$, and lanthanide tetrad effect. Contrib Mineral Petrol 123: 323-333

Blight JHS, Crowley QG, Petterson MG, Cunningham D (2010a) Granites of the southern Mongolia Carboniferous arc: new geochronological and geochemical constraints. Lithos 116: 35-52

Blight JHS, Petterson MG, Crowley QG, Cunningham D (2010b) The Oyut Ulaan volcanic group: stratigraphy, magmatic evolution and timing of Carboniferous arc development in SE Mongolia. J Geol Soc, London 167: 491-509

Bonin B (2007) A-type granites and related rocks: evolution of a concept, problems and prospects. Lithos 97: 1-29

Bonin B (2008) Death of super-continents and birth of oceans heralded by discrete A-type granite igneous events: the case of the Variscan-Alpine Europe. J Geosci 53: 237-252

Boynton WV (1984) Cosmochemistry of the rare earth elements: meteorite studies. In: HENDERSON P (ed) Rare Earth Element Geochemistry. Elsevier, Amsterdam, pp 63-114

Buriánek D, Hanžl P, Budil P, Gerdes A (2012) Evolution of the early Permian volcanic-plutonic complex in the western part of the Permian Gobi-Altay rift (Khar Argalant Mts., SW Mongolia). J Geosci 57: 105-126

Buslov MM, Safonova IY, Watanabe T, Obut OT, Fujiwara Y, Iwata K, Semakov NN, Sugai Y, Smirnova LV, Kazansky AY (2001) Evolution of the Paleo-Asian Ocean (Altai-Sayan Region, Central Asia) and collision of possible Gondwana-derived terranes with the southern marginal part of the Siberian Continent. Geosci J 5: 203

Chen B, Arakawa Y (2005) Elemental and Nd-Sr isotopic geochemistry of granitoids from the West Junggar foldbelt (NW China), with implications for Phanerozoic continental growth. Geochim Cosmochim Acta 69: 1307-1320

Chen B, JAHN BM (2004) Genesis of post-collisional granitoids and basement nature of the Junggar Terrane, NW China: Nd-Sr isotopic and trace element evidence. J Asian Earth Sci 23: 691-703
Cox AV, Dalrymple GB (1967) Statistical analysis of geomagnetic reversal data and the precision of potassiumargon dating. J Geophys Res 72: 2603-2614

EBy GN (1992) Chemical subdivision of the A-type granitoids: petrogenetic and tectonic implications. Geology 20: 641-644

Frost CD, Frost BR (2011) On ferroan (A-type) granitoids: their compositional variability and modes of origin. J Petrol 52: 39-53

Frost BR, Barnes CG, Collins WJ, Arculus RJ, Ellis DJ, Frost CD (2001) A geochemical classification for granitic rocks. J Petrol 42: 2033-2048

Grebennikov AV (2014) A-type granites and related rocks: petrogenesis and classification. Russ Geol Geophys 55: 1354-1356

IRBER W (1999) The lanthanide tetrad effect and its correlation with $\mathrm{K} / \mathrm{Rb}, \mathrm{Eu} / \mathrm{Eu}$, $\mathrm{Sr} / \mathrm{Eu}, \mathrm{Y} / \mathrm{Ho}$, and $\mathrm{Zr} / \mathrm{Hf}$ of evolving peraluminous granite suites. Geochim Cosmochim Acta 63: 489-508

JAHN BM (2004) The Central Asian Orogenic Belt and growth of the continental crust in the Phanerozoic. In: Malpas J, Fletcher CJN, Ali JR, Aitchison JC (eds) Aspects of the Tectonic Evolution of China. Geological Society of London Special Papers 226: 73-100

JAHN BM, Wu FY, CHEN B (2000) Granitoids of the Central Asian Orogenic Belt and continental growth in the Phanerozoic. Trans Roy Soc Edinb, Earth Sci 91: 181-193

JANOUŠEK V, FARROW CM, ERBAN V (2006) Interpretation of whole-rock geochemical data in igneous geochemistry: introducing Geochemical Data Toolkit (GCDkit). J Petrol 47: 1255-1259

Jiang YD, Sun M, Zhao GC, Yuan C, Xiao W, Xia XP, Long XP, Wu FY (2010) The 390 Ma high-T metamorphic event in the Chinese Altai: a consequence of ridgesubduction? Amer J Sci 310: 1421-1452

JiAng YD, Sun M, Kröner A, TumurkhuU D, Long XP, ZhaO GC, Yuan C, Xiao WJ (2012) The high-grade Tseel Terrane in SW Mongolia: an Early Paleozoic arc system or a Precambrian sliver? Lithos 142-143: 95-115

KAPUSTIN YL (1972) Zircophyllite - the zirconium analogue of astrophyllite. Zap Vses Mineral Obshch 101: 459-463 (in Russian)

Kovalenko VI, Yarmolyuk VV, Kovach VP, Kotov AB, Kozakov IK, SAlnikova EB (1996) Sources of Phanerozoic granitoids in Central Asia: $\mathrm{Sm}-\mathrm{Nd}$ isotope data. Geochem Int 34: 628-640

Kröner A, Lehmann J, Schulmann K, Demoux A, Lexa O, Tomurkhuu D, Štípská P, Liu D, Wingate MTD (2010) Lithostratigraphic and geochronological constraints on the evolution of the Central Asian Orogenic Belt in SW Mongolia: Early Paleozoic rifting followed by Late Paleozoic accretion. Amer J Sci 310: 523-574

Litvinovsky BA, Jahn BM, Zanvilevich AN, Saunders A, Poulain S, Kuzmin DV, Reichow MK, Titov AV (2002) 
Petrogenesis of syenite-granite suites from the Bryansky Complex (Transbaikalia, Russia): implications for the origin of A-type granitoid magmas. Chem Geol 189: 105-133

LiU W, LiU XJ, LiU LJ (2013) Underplating generated A- and I-type granitoids of the East Junggar from the lower and the upper oceanic crust with mixing of mafic magma: insights from integrated zircon $\mathrm{U}-\mathrm{Pb}$ ages, petrography, geochemistry and $\mathrm{Nd}-\mathrm{Sr}-\mathrm{Hf}$ isotopes. Lithos 179: 293-319

Long X, Yuan C, Sun M, Xiao W, Zhao G, Wang Y, Cai K, XIA X, XIE L (2009) Detrital zircon ages and Hf isotopes of the early Paleozoic flysch sequence in the Chinese Altai, NW China: new constrains on depositional age, provenance and tectonic evolution. Tectonophysics 480: 213-231

Mao QG, Xiao WJ, Fang TH, Windley BF, Sun M, Ao SJ, Zhang JE, Huang XK (2014) Geochronology, geochemistry and petrogenesis of Early Permian alkaline magmatism in the Eastern Tianshan: implications for tectonics of the Southern Altaids. Lithos 190-191: 37-51

Merlet C (1994) An accurate computer correction program for quantitative electron probe microanalysis. Microchim Acta 114/115: 363-376

McDonough WF, Sun SS (1995) The composition of the Earth. Chem Geol 120: 223-253

Pillonen PC, Lalonde AE, McDonald AM, Gault RA (2000) Niobokupletskite, a new astrophyllite-group mineral from Mont Saint-Hilaire, Quebec, Canada: description and crystal structure. Canad Mineral 38: 627-639

Pillonen PC, Lalonde AE, McDonald AM, Gault RA, LARSEN AO (2003) Insights into the astrophyllite group I. Nomenclature, composition and development of a standardized general formula. Canad Mineral 41: 1-26

Sokolova E (2012) Further developments in the structure topology of the astrophyllite-group minerals. Mineral Mag 76: 863-882

Soejono I, Buriánek D, Svojtka M, Žáček V, Čáp P, JANOUŠEK V (2016) Mid-Ordovician and Late Devonian magmatism in the Togtokhinshil Complex: new insight into the formation and accretional evolution of the Lake Zone (Western Mongolia). J Geosci 61: 5-23

SteIger RH, JäGER E (1977) Subcommission on Geochronology: convention on the use of decay constants in geoand cosmochronology. Earth Planet Sci Lett 36: 359-362

Sun M, Yuan C, Xiao W, Long Xia X, Zhao G, Lin S, Wu F, KRÖNER A (2008) Zircon U-Pb and Hf isotopic study of gneissic rocks from the Chinese Altai: progressive accretionary history in the early to middle Palaeozoic. Chem Geol 247: 352-383

Sylvester PJ (1989) Post-collisional alkaline granites. J Geol 97: 261-280

ŞEngör A, Natal'in B, Burtman V (1993) Evolution of the Altaid tectonic collage and Paleozoic crustal growth in Eurasia. Nature 364: 299-307

Tomurtogoo O (1997) A new tectonic scheme of the Paleozoides in Mongolia. Mongolian Geoscientist 3: $12-17$

Wang Q, Wyman DA, Zhao ZH, Xu JF, Zheng HB, Xiong XL, DAi DX, Li HC, Chu ZY (2007) Petrogenesis of Carboniferous adakites and $\mathrm{Nb}$-enriched arc basalts in the Alataw area, northern Tianshan range (western China): implications for Phanerozoic crustal growth in the Central Asia Orogenic Belt. Chem Geol 236: 42-64

Wang ZG, Chen YL, Dong ZS, Wu MQ, Zhang J (1993) The high-alkaline intrusive rock belts in northern Xinjiang: their geology, geochemistry and genesis. In: Tu GZ (ed) Progress of Solid-Earth Sciences in Northern Xinjiang, China. Science Publishing House, Beijing, 163-172 (in Chinese)

Whalen JB, Currie KL, Chappell BW (1987) A-type granites: geochemical characteristics, discrimination and petrogenesis. Contrib Mineral Petrol 95: 407-419

Wu FY, Sun DY, Li HM, JAhn BM, Wilde SA (2002) A-type granites in northeastern China: age and geochemical constraints on their petrogenesis. Chem Geol 187: $143-173$

Xiao WJ, Windley BF, Badarch G, Sun S, Li J, Qin K, WANG Z (2004) Palaeozoic accretionary and convergent tectonics of the southern Altaids: implications for the growth of central Asia. J Geol Soc, London 161: $1-4$

Yang W-B, Niu HC, Shan Q, Sun WD, Zhang H, Li NB, JIANG YH, YU XY (2014) Geochemistry of magmatic and hydrothermal zircon from the highly evolved Baerzhe alkaline granite: implications for $\mathrm{Zr}-\mathrm{REE}-\mathrm{Nb}$ mineralization. Miner Depos 49: 451-470

Zhang X, Yuan L, Xue F, Yan X, Mao Q (2015) Early Permian A-type granites from central Inner Mongolia, north China: magmatic tracer of post-collisional tectonics and oceanic crustal recycling. Gondwana Res 28: $311-327$

Zonenshain LP, Kuzmin MI, Natapov LM (1990) Geology of the USSR: A Plate-Tectonic Synthesis. American Geophysical Union, Geodynamics Series V 21, Washington, DC, pp $1-242$ 
